\title{
Sanitation of the buildings of the first mass series in Arkhangels
}

\author{
Nina Brenchukova ${ }^{1}$, Olga Popova ${ }^{1, *}$ and Vera Murgul ${ }^{2,3}$ \\ ${ }^{1}$ Northern (Arctic) Federal University named after M. V. Lomonosov, Arkhangelsk, 163000, Russia, \\ ${ }^{2}$ Moscow State University of Civil Engineering, Yaroslavskoe shosse, 26, Moscow, 129337, Russia \\ ${ }^{3}$ Peter the Great St.Petersburg Polytechnic University, Polytechnicheskaya, 29, St. Petersburg, \\ 195251, Russia
}

\begin{abstract}
The aim of the research is to analyze heat losses through the outward enclosing constructions of the buildings of the first mass series before and after the sanitation. As measures for sanitation, walls, ceilings, attic and ground floors were chosen for the insulation, as well as replacement of old wooden windows in polyvinylchloride windows with double-glazed pane, replacement of wooden entrance doors in warmed metal ones. Materials for insulation are chosen in accordance with the climatic features of Arkhangelsk. The calculations were carried out in accordance with the requirements of modern regulatory documents. Based on the obtained data, as well as the duration of the heating period and the current tariff, the amount of savings in thermal energy is determined. This information allows to conclude that the proposed activities are energy-efficient. Savings on heating after sanation: for «Stalin's serie», will be 272 thousand rubles, for «Khrushchev's serie» - about 410 thousand rubles and for «Brezhnev's serie» - 930 thousand rubles in year.
\end{abstract}

\section{Introduction}

A significant part of the Arkhangelsk housing consists of the buildings of the first mass series: «Stalin's serie», «Khrushchev's serie» and «Brezhnev's serie». The most active period of their erection was the $50 \mathrm{~s}-90 \mathrm{~s}$ of the 20th century. Then the main purpose of the construction was to solve the problem of housing shortage, which was achieved. But most of these buildings do not meet modern demands, in particular, the requirements of SP 50.13330 .2012 «Thermal protection of buildings» [1]. The subject of the research is sanitation, aimed at increasing their energy efficiency.

This topic is relevant in the territory of the CIS countries. Various aspects of this topic have been considered in many articles and scientific papers:

- methods of sanitation of buildings of the first mass series [2-4],

- technological features of reconstruction [5-8],

- the creation of a project for the organization of construction during reconstruction [9],

- calculation of costs for facade insulation and economic justification of the reconstruction $[10,11]$

\footnotetext{
* Corresponding author: oly-popova@yandex.ru
} 
- prospects for solving this problem [12].

The aim of the research is to analyze heat losses through the outward enclosing constructions of the buildings of the first mass series before and after the sanitation.

\section{Materials and methods}

The main objectives of the research are:

- selection of optimal thermal insulation options for different series depending on their design features and climatic conditions in Arkhangelsk;

- calculation of the thermal properties of walls, windows, doors, covers, basement and attic floors before and after sanitation in accordance with the foregoing document;

- determination of the heating costs according to the current tariffs before and after the sanitation.

The following assumptions and limitations are used in this article:

- $\quad$ only the most common buildings in Arkhangelsk are considered;

- in the calculation of energy efficiency of «Stalin's serie», «Khrushchev's serie» and «Brezhnev's serie», not considering their physical depreciation and its effect on the thermal properties of the enclosing structures;

- $\quad$ only calculation methods based on the experience of design solutions are used, without using of instrumental survey of buildings;

- the estimate cost and recoupment of sanitation are not calculated.

Sanitation in this study is a kind of reconstruction aimed at achieving an energy saving effect (usually due to an increase in the resistance to heat transfer of the enclosing structures, renovation of heating systems and hot water supply) and the elimination of the moral deterioration of the building. The objects of the research are the most widespread in Arkhangelsk «Stalin's serie», «Khrushchev's serie» (Table 1).

The initial data for the heating engineering calculation are the climatic characteristics of Arkhangelsk, adopted in accordance with the formulary SP 131.13330.2012 «Construction climatology» [13] and STO 00044807-001-2006 «Thermal protective properties of building envelopes» [14]:

- $\quad$ the average temperature for the heating period $t_{\text {h.p. }}=-4.5^{\circ} \mathrm{c}$,

- duration of the heating period $\mathrm{z}_{\text {h.p. }}=250$ days,

- $\quad$ the air temperature of the coldest five-day period, with a security of $0,92: t_{5}=-33^{\circ} \mathrm{c}$,

- the external temperature $t_{0}=t_{5}=-33^{\circ} \mathrm{c}$,

- $\quad$ atmospheric moisture external capacity $\varphi_{\text {ext }}=85 \%$,

- the temperature of the internal air $t_{\text {int }}=21^{\circ} \mathrm{c}$, because $t_{5}=-33^{\circ} \mathrm{c}<31^{\circ} \mathrm{c}$; Atmospheric moisture inside capacity $\varphi_{\text {int }}=55 \%$, which conforms to the normal humidity regime.

- humidity zone: wet.

- operating conditions of enclosing structures: B.

The procedure of heat engineering calculation of enclosing structures is described in the above-mentioned formulary SP 50.13330.2012 «Thermal protection of buildings» [1], formulary SP 23-101-2004 «Design of thermal protection of buildings» [15] and State Standard R 54851-2011 «Nonuniform building enveloping structures» [16]. 
Table 1. Researched series of buildings and their characteristics.

\begin{tabular}{|c|c|c|c|c|}
\hline $\begin{array}{l}\text { Group of the } \\
\text { building }\end{array}$ & «Stalin’s serie» & \multicolumn{2}{|c|}{ «Khrushchev’s serie» } & «Brezhnev’s serie» \\
\hline Serie & II-05 & $1-464$ & $1-447$ & $114-85$ \\
\hline $\begin{array}{c}\text { Years of } \\
\text { construction }\end{array}$ & $1954-1959$ & \multicolumn{2}{|c|}{$1958-1964$} & $1974-2005$ \\
\hline $\begin{array}{l}\text { Structural } \\
\text { scheme }\end{array}$ & Wall, cross & Wall, cross & Wall, cross & Wall, cross \\
\hline Walls & $\begin{array}{c}\text { ceramic brick (640 } \\
\mathrm{mm})\end{array}$ & $\begin{array}{l}\text { single-layer panels } \\
\text { of shungizit con- } \\
\text { crete }(350 \mathrm{~mm})\end{array}$ & $\begin{array}{l}\text { silicate brick (640 } \\
\mathrm{mm})\end{array}$ & $\begin{array}{c}\text { silicate brick (640 } \\
\mathrm{mm})\end{array}$ \\
\hline floors & $\begin{array}{l}\text { concrete round- } \\
\text { hollow slabs } \\
(220 \mathrm{~mm})\end{array}$ & $\begin{array}{c}\text { solid reinforced } \\
\text { concrete slabs }(100 \\
\mathrm{mm})\end{array}$ & $\begin{array}{l}\text { concrete round- } \\
\text { hollow slabs } \\
(220 \mathrm{~mm})\end{array}$ & $\begin{array}{l}\text { concrete round- } \\
\text { hollow slabs } \\
(220 \mathrm{~mm})\end{array}$ \\
\hline Roof & $\begin{array}{l}\text { pitched, with tech- } \\
\text { nical floor }\end{array}$ & $\begin{array}{l}\text { Flat combined, } \\
\text { covering- roll } \\
\text { flashing }\end{array}$ & $\begin{array}{l}\text { pitched, with tech- } \\
\text { nical floor }\end{array}$ & $\begin{array}{l}\text { pitched with tech- } \\
\text { nical floor, cover- } \\
\text { ing- roll flashing }\end{array}$ \\
\hline $\begin{array}{c}\text { Cellar/ } \\
\text { technical floor }\end{array}$ & warm & cold & warm & cold \\
\hline windows & \multicolumn{4}{|c|}{ wooden with double glaring in separate window sashes } \\
\hline entrance doors & \multicolumn{4}{|c|}{ wooden } \\
\hline $\begin{array}{c}\text { Number of } \\
\text { entrances }\end{array}$ & 2 & 4 & 4 & 4 \\
\hline $\begin{array}{c}\text { Number of } \\
\text { Floors }\end{array}$ & 5 & 5 & 5 & 9 \\
\hline $\begin{array}{l}\text { Height of the } \\
\text { floor, } m\end{array}$ & 3 & 2,5 & 2,5 & 2,48 \\
\hline
\end{tabular}

\section{Results}

Based on the climatic characteristics of Arkhangelsk, as well as the structural features of the buildings, the following optimal methods of insulation of walls, coatings, socle and attic floors, materials for filling window opening and doorways were selected (Table 2).

Table 2. Materials for insulation of enclosing structures in Arkhangelsk.

\begin{tabular}{|c|c|c|c|c|}
\hline $\begin{array}{c}\text { The group } \\
\text { of build- } \\
\text { ings }\end{array}$ & «Stalin's serie» & \multicolumn{2}{|c|}{ «Khrushchev's serie» } & $\begin{array}{c}\text { «Brezhnev's } \\
\text { serie» }\end{array}$ \\
\hline Serie & II-05 & $1-464$ & $1-447$ & $114-85$ \\
\hline Walls & $\begin{array}{c}\text { Ventilated facade } \\
\text { with mineral } \\
\text { wool insulation } \\
\text { (120mm) }\end{array}$ & $\begin{array}{c}\text { Ventilated facade } \\
\text { with mineral wool } \\
\text { insulation (120mm) }\end{array}$ & $\begin{array}{c}\text { Ventilated facade } \\
\text { with mineral wool } \\
\text { insulation } \\
(120 \mathrm{~mm})\end{array}$ & $\begin{array}{c}\text { Ventilated facade } \\
\text { with mineral wool } \\
\text { insulation } \\
(120 \mathrm{~mm})\end{array}$ \\
\hline $\begin{array}{c}\text { Attic floors } \\
\text { / combined } \\
\text { roofs }\end{array}$ & $\begin{array}{c}\text { mineral wool } \\
\text { insulation }(200 \\
\mathrm{mm})\end{array}$ & $\begin{array}{c}\text { mineral wool insu- } \\
\text { lation }(200 \mathrm{~mm})\end{array}$ & $\begin{array}{c}\text { mineral wool } \\
\text { insulation }(200 \\
\text { mm) }\end{array}$ & $\begin{array}{c}\text { mineral wool } \\
\text { insulation }(200 \\
\text { mm) }\end{array}$ \\
\hline
\end{tabular}




\begin{tabular}{|c|c|c|c|c|}
\hline $\begin{array}{c}\text { Socle } \\
\text { floors / } \\
\text { floors on } \\
\text { the ground } \\
\text { and sand from } \\
\text { sintered perlite } \\
(100 \mathrm{~mm}), \text { miner- } \\
\text { al wool insula- } \\
\text { tion }(50 \mathrm{~mm})\end{array}$ & $\begin{array}{c}\text { Crushed stone } \\
\text { mineral wool insu- } \\
\text { lation }(260 \mathrm{~mm})\end{array}$ & $\begin{array}{c}\text { mineral wool } \\
\text { insulation } \\
(260 \mathrm{~mm})\end{array}$ & $\begin{array}{c}\text { mineral wool } \\
\text { insulation } \\
(260 \mathrm{~mm})\end{array}$ \\
\hline windows & \multicolumn{2}{|c|}{ replacement on a double-glazed window in a single cover from glass with a firm } \\
selective covering
\end{tabular}

After calculating the heat loss through the enclosing structures before and after insulation, an overpayment for heating was calculated. The results of calculations of the enclosing structures of these series are presented in Table 3.

Table 3. Results of heat engineering calculation of enclosing structures.

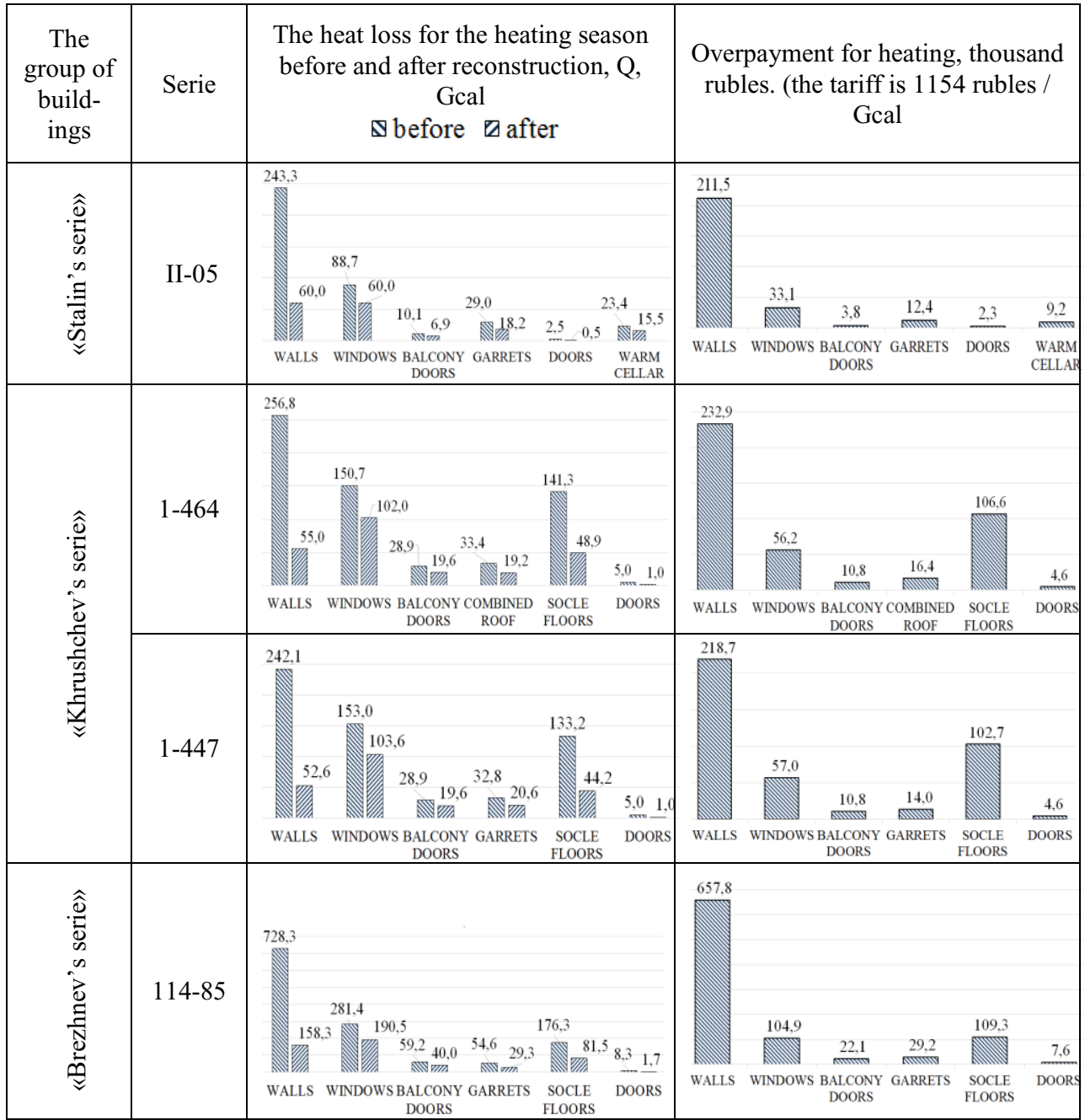

After the sanitation, heat losses were reduced:

- for walls - by $75-79 \%$,

- $\quad$ for windows and balcony doors - by $32 \%$, 
- for garret floors - by $37-46 \%$,

- for a combined roof - by $43 \%$,

- for doors - by $20-80 \%$,

- for a warm cellar - by $66 \%$,

- for a socle floor - by 54-67\% compared to losses of heat before reconstruction.

The savings on heating fees for the period with stable average daily outside temperatures not more than $+8{ }^{\circ} \mathrm{C}$ (heating period) will be:

- for «Stalin's series» II-05 - 272 thousand rubles,

- for panel «Khrushchev's serie» 1-464 - 427 thousand rubles,

- for brick «Khrushchev's serie» 1-447 - 407 thousand rubles,

- for «Brezhnev's serie»114-85 - 930 thousand rubles.

\section{Discussion}

The results of this study were the losses of heat through the enclosing structures before and after the sanation. It is obvious that heat losses after the sanitation decreased significantly.

The less heat loss through the building's enclosing structures, the less energy is required to deliver from the city's thermoelectric power station. Consequently, such insulation will lead to a significant reduction in payments for heating.

Besides, in today's world, one of the first places is the problem of energy saving. Taking into account that the main consumers of energy is urban development, namely residential buildings, one of the methods for solving it is to increase the energy performance of existing buildings. The offered methods can be useful for the development of the construction branch in this direction.

\section{Conclusions}

The buildings of the first mass series do not meet modern requirements for thermal protection.

This study shows that the sanation of residential buildings of the first mass series can significantly improve their quality, reduce moral depreciation.

The most optimal for Arkhangelsk are the following measures: warming the walls with a hinged ventilated facade, warming the socle and garret floors, combined roof with a mineral wool insulation, replacing windows and doors.

The greatest effect is achieved when the walls, the socle and garret floors, combined roof are insulated.

The greatest savings in heating will be achieved from the sanitation of the «Khrushchev's serie» and the «Brezhnev's serie».

It should be noted that in the context of this research, it can be concluded only about the energy effectiveness of the selected methods of sanitation of the buildings of the first mass series. It is difficult to talk about economic effectiveness. The amounts of overpayment for heating are known and significant, but there is not enough cost for sanitation work to assess the payback. This will become the purpose of my further research.

\section{References}

1. Russian Standard SP 50.13330.2012 (2012)

2. N.A. Brenkukova, G.V. Severova, A.L. Shepelev, Building science - XXI: theory, constitution, practice, innovations Northern-arctic region (2017) 
3. A.A. Afanasyev, E.P. Matveyev, Reconstaction of residential buildings Part I. technologies of reconstruction of operation security residential buildings (Moscow, 2008)

4. B.V. Zhadanovskij, Industrial and civil construction 10, 59-60 (2009)

5. K.A. Grigorenko, O.V. Petreneva, Herald of PSTU 7(1), 47-55 (2016)

6. S.N. Bulgakov, V.V. Leontiev, Recompensed reconstruction of residential buildings of the first mass series (Publishing House of the DIA, Moscow, 2016)

7. A.L. Shepelev, Collection of abstract information of ASTU's scientists about the results of research and development. Development of organizational and technological documentation for the reconstruction of a five-story large-panel residential building in Arkhangelsk (Arkhangelsk, 2007)

8. A.L. Shepelev, S.N. Sultanov, A.L. Dyatlov, Collection of abstract information of ASTU's scientists about the results of research and development. 4. Organizational and technological documentation for the reconstruction of a five-story large-panel residential building in Arkhangelsk (Arkhangelsk, 2007)

9. A.L. Shepelev, N.N. Chernenko, Collection of abstract information of ASTU's scientists about the results of research and development, 4, Technology and organization of work in the reconstruction of a five-story brick apartment house (Arkhangelsk, 2008)

10. D.N. Tseitin, N.I. Vatin, D.V. Nemova, P.P. Rymkevich, A.S. Gorshkov, ISSN 23046295 40, 20-31 (2016)

11. S.N. Ovsyannikov, A.N. Ovsyannikov, Herald of TASU 2, 105-112 (2010)

12. A.V. Spirin, A.S. Grishina, Insulation of outside walls with help of the reconstruction of brick buildings, Perm National Research Polytechnic University

13. Russian Standard SP 131.13330.2012 (2012)

14. The standard of organizations STO 00044807-001-2006 (2006)

15. Russian Standard SP 23-101-2004 (2004)

16. State Standard R 54851-2011 (2012) 